\title{
The role of employee performance mediation on organizational performance
}

\author{
Efi Herawati; Syamsurijal Tan; Tona Aurora Lubis*; M. Syurya Hidayat
}

Doctoral Program in Economics, Postgraduate, Universitas Jambi, Indonesia

*To whom correspondence should be addressed.Email: tonalubis@gmail.com

\begin{tabular}{|l|l|l|l|l|}
\hline DOI: & Received: & Revised: & Accepted: & Published: \\
10.22437/ppd.v8i6.11018 & 13.11 .2020 & 09.01 .2021 & 10.01 .2021 & 01.02 .2021 \\
\hline
\end{tabular}

\begin{abstract}
.
This study aimed to analyze the effect of employee training and development, motivation, work environment, employee competence on employee performance, and organizational performance. This study also aims to analyze employee performance as a mediating variable on organizational performance. The method of this research used SEM-PLS analysis. This research used all civil servants employees in The Regional Technical Implementing Unit for Goods Quality and Certification Testing Center (UPTD BPSMB) of the Jambi Province, Indonesia. This research concluded that Organizational performance is influenced by motivation, employee competence, work environment, and employee performance. Training and development, motivation, and work environment affect employee performance. Training and development, employee competence, work environment affect organizational performance mediated by employee performance. However, the influence of motivation on organizational performance cannot be mediated by employee performance.
\end{abstract}

Keywords: Employee, Organizational, Performance

JEL Classification: M12, M53, M54

\section{INTRODUCTION}

Employee performance and organizational performance are very closely related. The achievement of organizational goals cannot be separated from the resources owned by the organization. It runs by employees who play an active role as actors in achieving their goals (Pasolong, 2019).

The Regional Technical Implementing Unit for Goods Quality and Certification Testing Center (UPTD BPSMB) of the Jambi Province, Indonesia, is the executor of the Industry and Trade Office's operational, technical duties. As the only quality testing and certification agency in Jambi province, UPTD BPSMB has the task of carrying out testing, calibration, and quality certification of goods and providing technical guidance to producers, exporters, and the business world as the general public.

The results from The Public Satisfaction Index Survey of the UPTD BPSMB in 2018 result about $76.02 \%$, it is included in the IKM conversion interval range with good service quality (score B). It indicates that UPTD BPSMB's performance hasn't optimal yet. Judging from the science of Human Resource Management, many factors affect organizational performance. 
One of the successes of organizational performance can be seen from employee training provided by the organization. Kinisa (2019) found that the T \& D (Training \& development) program increased employee performance and overall organizational performance in Tanzania's banking industry. Meanwhile, Samwel (2018) found that employee training significantly affects drilling companies' performance in the Geita, Shinyanga, and Mara regions in Tanzania. However, the study also found a lack of effective training and development policies in drilling companies. Meanwhile, Mangkunegara \& Agustine (2016) conducted a study at Hospital X in Indonesia, showing that training, motivation, and work environment simultaneously have a significant positive effect on doctor performance.

Motivation is the thrust of an employee to work. Motivation can affect many things in an organization. Geelmaale's research (2019) shows that if employees are positively motivated and rewarded, it will increase their worthiness and productivity to improve organizational performance. Meanwhile, Mangkunegara \& Agustine's (2016) research where motivation is reflected by two indicators, namely intrinsic and extrinsic motivation, shows that training, motivation, and work environment simultaneously have a significant positive effect on the performance of doctors in X hospital in Indonesia. While Nizam \& Shah's research in Pakistan (2015) concluded by testing job performance and recognizing employee performance, and motivating them by giving appropriate rewards, employees will be satisfied. Thus, their output level increases and improves organizational performance.

Employee competencies are skills and knowledge supported by work attitudes and their application in high-performance tasks and jobs that refer to the specified job requirements. Therefore, competent employees are an essential factor if a company survives in a rapidly changing environment. Research conducted by Osei \& Ackah (2015) shows that competent employees will significantly contribute to the entire organization's performance. Meanwhile, the research findings carried out by Hanafi \& Ibrahim (2018) revealed that employee competence has a direct impact on service performance and customer experience and that it is significant, and that customer experience has a direct impact on service performance.

The work environment has both positive and negative effects on the psychological and well-being of employees. Research conducted in Kenya by Gitonga \& Gachunga (2015) shows that the work environment significantly and positively affects government ministries' organizational performance. The psychosocial environment, as the most significant factor, has a significant positive relationship. Meanwhile, Kegel (2017) shows evidence that the design of a physical work environment can positively or negatively affect organizational success. The physical work environment affects organizational performance in performance, collaboration, innovation, effective human resource management, and profitability. The physical work environment also affects employee performance, such as engagement, performance, welfare, and satisfaction.

Employee performance is a measure of an employee's performance. Irfan et al. (2019) argue that staff performance is closely related to organizational goals or individual staff performance. Samwel's (2018) research reveals that private organizations practice performance management and have an effective performance management system to evaluate their employees' performance. Meanwhile, Kumar's research (2014) states that performance appraisal positively impacts employee abilities and organizational performance.

Based on empirical studies, there is an effect of training and development, 
motivation, work competence, work environment, and employee performance on organizational performance. Therefore, there are research gaps related to employee performance that can be examined at UPTD BPSMB.

Training and development is an essential aspect of human resource development. Training and development will provide opportunities for employees to perform better and opportunities for careers in organizations. Owotunse's research (2018) shows that training and development have a significant relationship with employee performance and productivity. While Younas et al.'s (2018) research on the banking sector in Pakistan revealed that development leads to better employee performance, training and development improves employee performance.

Motivation determines the direction for employees to excel in the organization. Research by Olafsen et al. (2015) stated that intrinsic work motivation in salary provision does not affect employee performance, but salary payment's fairness impacts employee performance. Research by Kuvaas et al. (2017) shows that employees work better if they are intrinsically motivated. Besides, Shahzadi et al. (2014) showed that intrinsic motivation for teachers in Pakistan has a significant impact on their performance. Research by Mohamud et al. (2017) shows that financial rewards and job enrichment have a significant and positive effect on employee performance and employee motivation that affect Hormuud Company's performance in Mogadishu, Somalia. Meanwhile, Ali et al. (2016) stated that motivation plays a vital role in employee performance and job satisfaction in the IT Park sector in Peshawar, Pakistan.

Employee competency improvement can be made through increasing employee knowledge, improving employee skills, and improving employee attitudes. On the other hand, employees' motivation will arise from the employees' external motivation and internal motivation. Research by Kurniawan et al. (2018) shows that competence and motivation positively affect employee performance. At the same time, Martini et al. (2018) found that employee competence and organizational commitment dimensions showed a significant positive effect on employee performance.

The existence of a work environment that is conducive and comfortable will create enthusiasm from employees in working performance in each job. Research by Putri et al. (2019) shows that the work environment affects employee performance. A good work environment, adequate facilities, a conducive workplace, and a good relationship with colleagues and superiors will provide comfort to employees. When employees feel comfortable and support by their social environment, employees will be encouraged to work well. Meanwhile, Research Khoso et al. (2016) revealed that the factors of leadership support, job assistance, and physical work environment are positively correlated with employees' performance in five private hospitals in Hyderabad, India.

Thus, there is an effect of training and development, motivation, work competence, and work environment on employee performance from several studies. Therefore, there is a research gap about employee performance that can be examined at UPTD BPSMB.

Previous empirical research states that employee training and development can improve employee performance and productivity (Owotunse, 2018 and Younas et al., 2018). It will also improve organizational performance (Kinisa, 2019; Samwel, 2018; Mangkunegara \& Agustine, 2016).

Motivation affects employee performance (Mohamud et al., 2017; and Ali et al., 2016). Meanwhile, Geelmaale (2019), Mangkunegara \& Agustine (2016), and Nizam \& 
Shah (2015) found that motivation affects organizational performance.

Employee competence can improve employee performance (Kurniawan et al. 2018 and Martini et al., 2018). It will also improve organizational performance (Osei \& Ackah, 2015 and Hanafi \& Ibrahim, 2018). The work environment can improve employee performance (Putri et al., 2019 and Khoso et al., 2016); besides, it will also improve organizational performance (Kegel, 2017 and Gitonga \& Gachunga, 2015).

According to previous studies' results, it can be formulated to influence training and development, motivation, work competence, and work environment on employee performance on organizational performance through employee performance. Therefore, a research gap related to employee performance as a mediator of organizational performance can be examined at UPTD BPSMB.

\section{METHODS}

This research is quantitative research with an explanatory type. This study used a survey method for all civil servants in UPTD BPSMB Jambi Province, with as many as 19 people. Data collection used a questionnaire with a 5-point Likert scale instrument (Strongly disagree to agree strongly). Furthermore, the operational definition of this research is in Table 1.

Table 1. Operational research variables

\begin{tabular}{|c|c|c|}
\hline Variable & Definition & Indicator \\
\hline $\begin{array}{l}\text { Employee } \\
\text { training and } \\
\text { development } \\
\text { (ETD) }\end{array}$ & $\begin{array}{l}\text { Employee training refers to programs that provide } \\
\text { information, new skills, or professional development } \\
\text { opportunities for employees (Olalere \& Adegnuba, 2013). }\end{array}$ & $\begin{array}{l}\text { 1.Instructor } \\
\text { 2.Participant } \\
\text { 3.Material } \\
\text { 4.Method } \\
\text { 5.Objective } \\
\text { 6. Target }\end{array}$ \\
\hline $\begin{array}{l}\text { Motivation } \\
(\mathrm{M})\end{array}$ & $\begin{array}{l}\text { Is an energetic force that forces or encourages the } \\
\text { maintenance of certain behaviors (Ezeali and Eziagu, 2009) }\end{array}$ & $\begin{array}{l}\text { 1.Intrinsic Motivation } \\
\text { 2.Extrinsic motivation }\end{array}$ \\
\hline $\begin{array}{l}\text { Employee } \\
\text { competencies } \\
\text { (EC) }\end{array}$ & $\begin{array}{l}\text { Competence shows the adequacy of knowledge and skills } \\
\text { that enable a person to act in various situations. (Hanafi \& } \\
\text { Ibrahim 2018) }\end{array}$ & $\begin{array}{l}\text { 1. Knowledge } \\
\text { 2.Skills } \\
\text { 3.Attitude }\end{array}$ \\
\hline $\begin{array}{l}\text { Work } \\
\text { environment } \\
\text { (WE) }\end{array}$ & $\begin{array}{l}\text { a place where certain work has to be done. It includes other } \\
\text { factors such as quality, quantity, process, procedure, and } \\
\text { benefits (Chaudhry et al. 2017) }\end{array}$ & $\begin{array}{l}\text { 1.Physical working } \\
\text { conditions } \\
\text { 2.Psychosocial } \\
\text { working conditions }\end{array}$ \\
\hline $\begin{array}{l}\text { Employee } \\
\text { performance } \\
(\mathrm{EP})\end{array}$ & $\begin{array}{l}\text { Job performance of an employee at work. It is considered a } \\
\text { critical component in organizational success (Shaikh et al. } \\
\text { 2017) }\end{array}$ & $\begin{array}{l}\text { 1. Work quantity } \\
\text { 2.Quality Work } \\
\text { 3.Punctuality } \\
\text { 4.Presence } \\
\text { 5. Ability cooperation }\end{array}$ \\
\hline $\begin{array}{l}\text { Organizational } \\
\text { Performance } \\
\text { (OP) }\end{array}$ & $\begin{array}{l}\text { The organizational performance consists of the actual output } \\
\text { or organizational results measured against the intended } \\
\text { output (Richard et al., 2009). Performance must be achieved } \\
\text { through items such as evaluation, testing, efficiency, } \\
\text { effectiveness, and quality (Bartoli \& Blatrix, 2015) }\end{array}$ & $\begin{array}{l}\text { 1.Internal } \\
\text { Effectiveness } \\
\text { 2.External } \\
\text { Effectiveness } \\
\text { 3.Internal Fairness }\end{array}$ \\
\hline
\end{tabular}

This research uses inferential statistical analysis in the form of a causality analysis of SEM (Structural Equation Modeling) based on component or variance (Partial Least Square or PLS). The initial research model is given in Figure 1. 


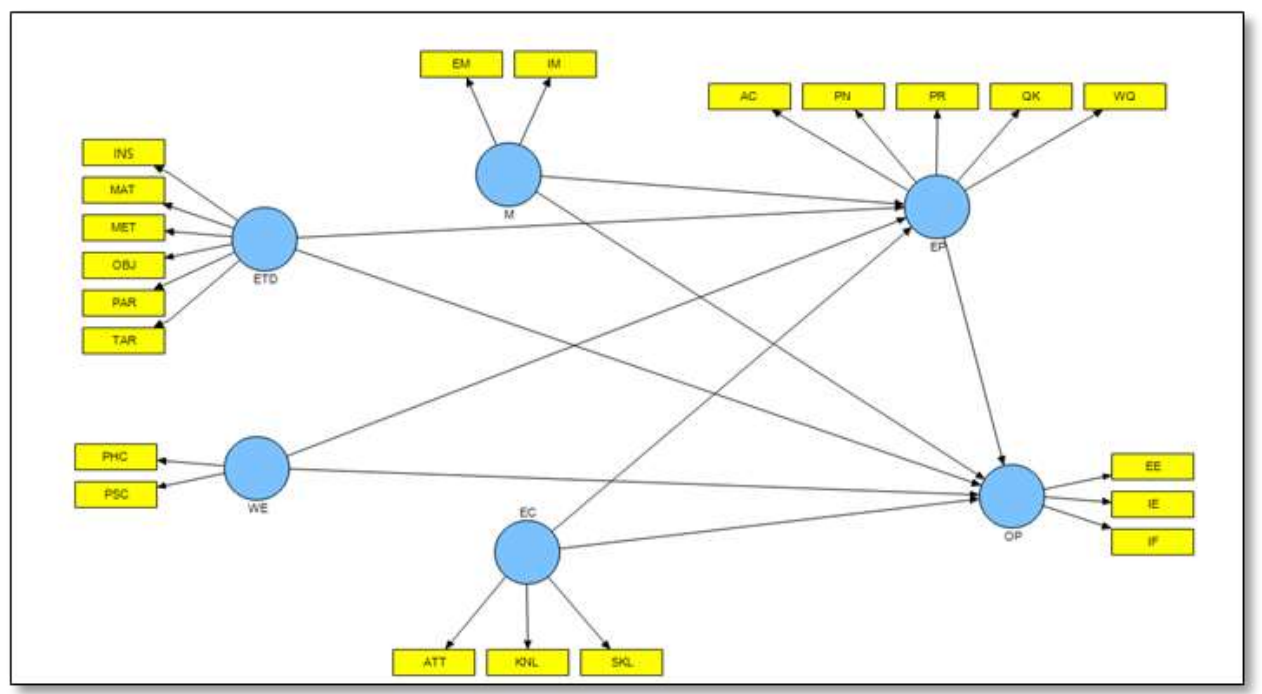

Figure 1. Initial research model

\section{RESULTS AND DISCUSSION}

Based on Table 2, the knowledge indicator, from the employee competencies variable, is in the medium category. Meanwhile, all other indicators of all existing variables are in the high category. It shows that the respondents provide a good picture of this study's indicators at the UPTD BPSMB

Table 2. The average score of the variables and research indicators

\begin{tabular}{|c|c|c|}
\hline Variable and Indicator & Average score & Category \\
\hline \multicolumn{3}{|l|}{ Employee training and development (ETD) } \\
\hline - Instructor (INS) & 3,526 & High \\
\hline - $\quad$ Participant (PAR) & 3,526 & High \\
\hline - $\quad$ Material (MAT) & 3,526 & High \\
\hline - $\quad$ Method (MET) & 3,316 & High \\
\hline - $\quad$ Objective $(\mathrm{OBJ})$ & 3,579 & High \\
\hline - $\quad$ Target (TAR) & 3,316 & High \\
\hline \multicolumn{3}{|l|}{ Motivation / motivation (M) } \\
\hline - Intrinsic Motivation (IM) & 3,052 & High \\
\hline - Extrinsic motivation (EM) & 3,368 & High \\
\hline \multicolumn{3}{|l|}{ Employee competencies (EC) } \\
\hline - Knowledge (KNL) & 3,000 & Medium \\
\hline - $\quad$ Skills (SKL) & 3,421 & High \\
\hline - $\quad$ Attitude (ATT) & 3,473 & High \\
\hline \multicolumn{3}{|l|}{ Work environment/ work environment (WE) } \\
\hline - $\quad$ physical working conditions (PWC) & 3,316 & High \\
\hline - $\quad$ psychosocial working conditions (PSC) & 3,358 & High \\
\hline \multicolumn{3}{|l|}{ Employee performance (EP) } \\
\hline - Work quantity (WQ) & 3,684 & High \\
\hline - $\quad$ Quality Work (QK) & 3,210 & High \\
\hline - $\quad$ Punctuality (PN) & 3,368 & High \\
\hline - $\quad$ Presence (PR) & 3,473 & High \\
\hline - $\quad$ Ability cooperation (AC) & 3,316 & High \\
\hline \multicolumn{3}{|l|}{ Organizational Performance (OP) } \\
\hline - Internal Effectiveness (IE) & 3,526 & High \\
\hline - $\quad$ External Effectiveness (EE) & 3,473 & High \\
\hline - Internal Fairness (IF) & 3,316 & High \\
\hline
\end{tabular}


Furthermore, Figure 2. is the calculation result of the initial research model. According to Ghozali (2008), the measurement model's convergent validity with reflective indicators can be seen from the correlation between item scores/indicators and their construct scores. This correlation is known as the loading factor (outer loading). Indicators are considered reliable if they have a positive correlation value above 0.70 . However, at the scale development research stage, loading 0.5 to 0.6 is still acceptable.

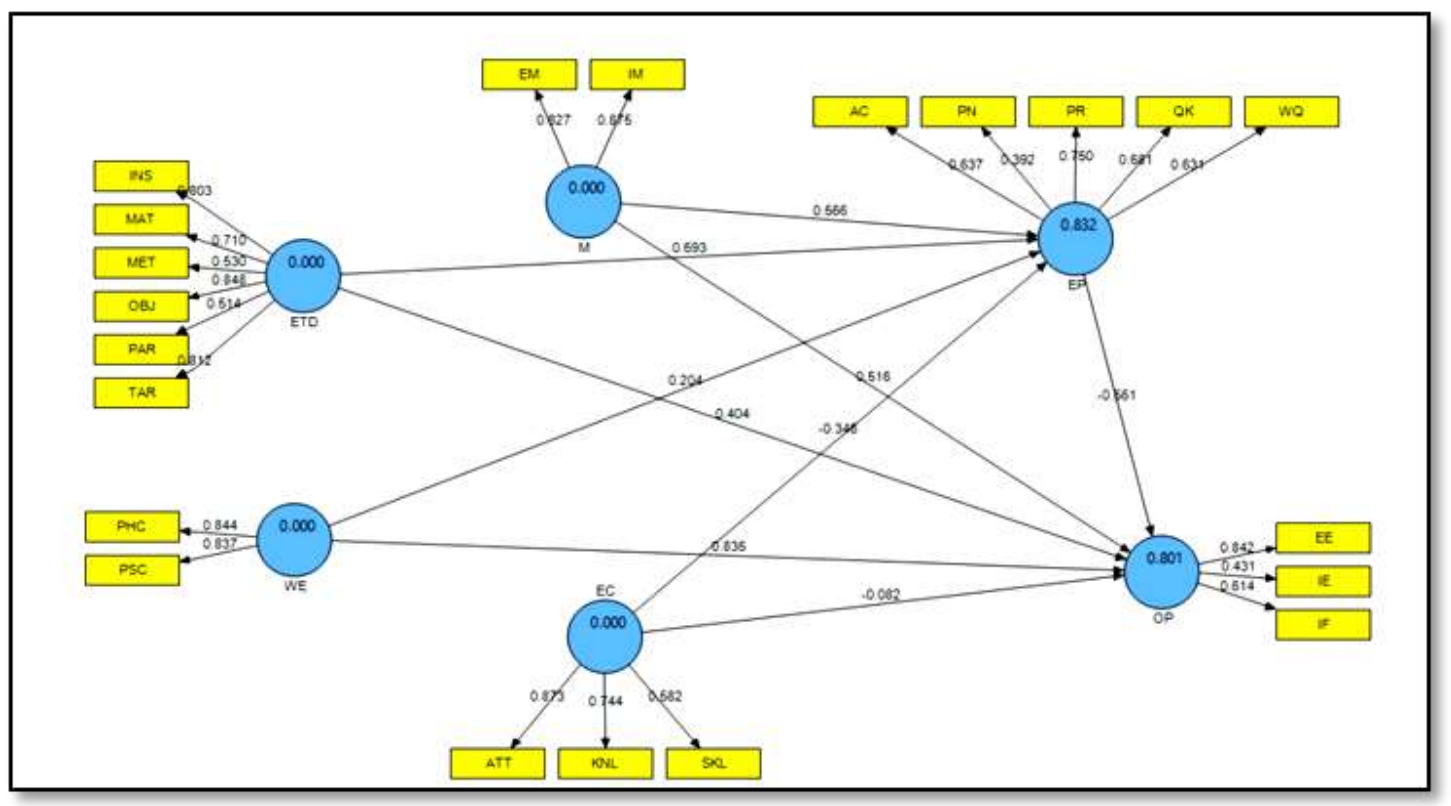

Figure 2. Calculation results of the initial research model

With this guideline (Ghozali, 2008), a research model that has dropped inappropriate indicators is then built. Figure 3. are the results of the calculation of the final research model.

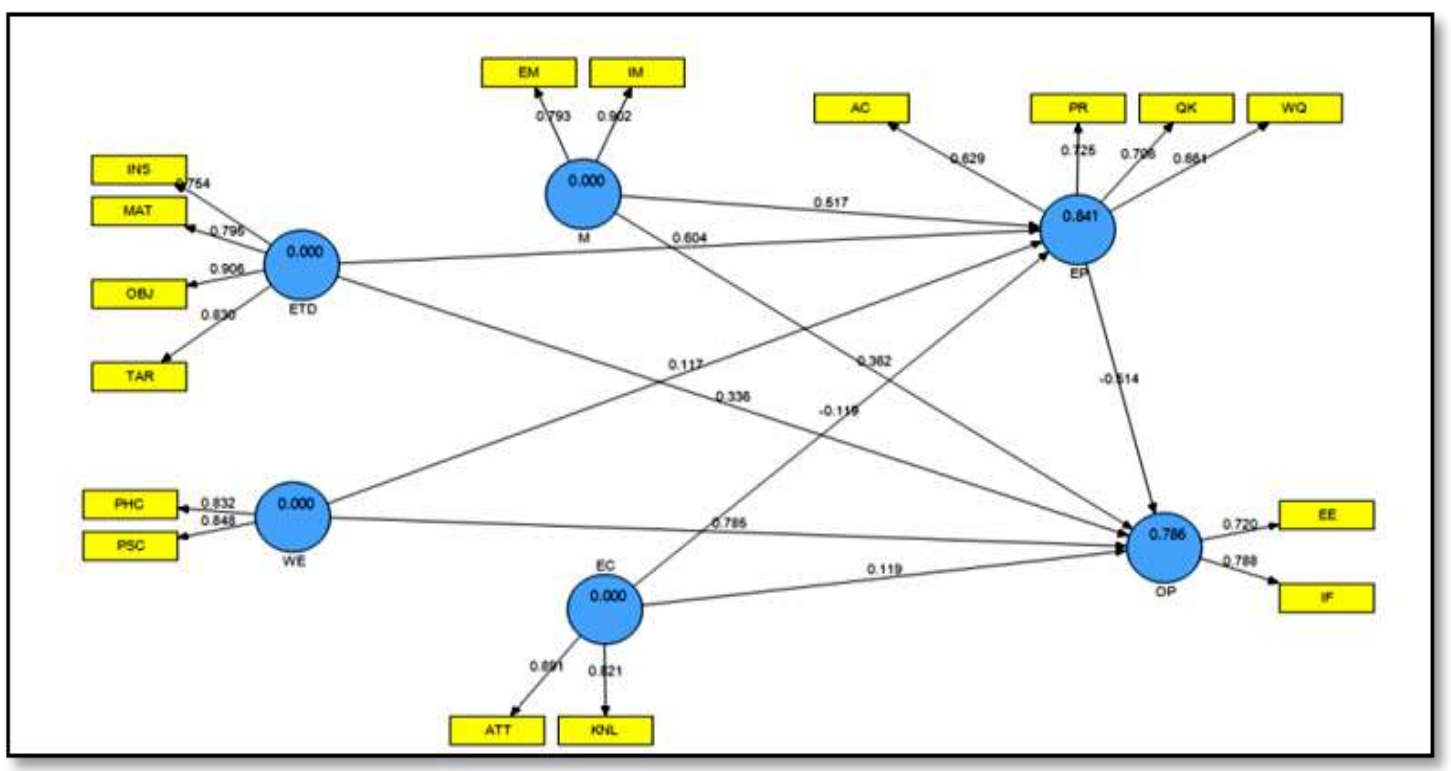

Figure 3. Second model calculation results

Based on the loading factor value (Figure 3), Average Variance Extracted, and Composite Reliability (Table 3 ), each variable's indicators are reliable and valid, reflecting their respective variables. 
Table 3. Average Variance Extracted and Composite Reliability

\begin{tabular}{cccc}
\hline Variable & Average Variance Extracted & Composite Reliability & Information \\
\hline EC & 0.733715 & 0.846188 & Valid \\
ETD & 0.677499 & 0.893213 & Valid \\
M & 0.721107 & 0.837398 & Valid \\
WE & 0.706072 & 0.827703 & Valid \\
EP & 0.463778 & 0.775232 & Valid \\
OP & 0.569798 & 0.725555 & Valid \\
\hline
\end{tabular}

I tested the structural model's goodness of fit against the inner model using predictive-relevance $(\mathrm{Q} 2)$ values. The predictive-relevance result shows that the diversity of data that can be explained by the model is $88.79 \%$. This result indicates that the research model has predictive-relevance and can be used for hypothesis testing.

Table 4. The R square model

\begin{tabular}{cl}
\hline Variable & R Square \\
\hline EP & 0.840992 \\
OP & 0.785658 \\
\hline
\end{tabular}

Table 5 illustrates the ability to reflect the effect between variables. Employee training and development (ETD) does not have a significant effect on organizational performance. It is due to the absence of comprehensive training and development planning at UPTD BPSMB. The results do not support the results of research conducted by Kinisa (2019), Samwel (2018), and Mangkunegara \& Agustine (2016).

Table 5. Total Effects (Mean, STDEV, T-Values)

\begin{tabular}{cccccr}
\hline & $\begin{array}{c}\text { Original } \\
\text { Sample (O) }\end{array}$ & $\begin{array}{c}\text { Sample } \\
\text { Mean (M) }\end{array}$ & $\begin{array}{c}\text { Standard } \\
\text { Deviation } \\
\text { (STDEV) }\end{array}$ & $\begin{array}{c}\text { Standard } \\
\text { Error } \\
\text { (STERR) }\end{array}$ & $\begin{array}{c}\text { T Statistics }(\mid \mathrm{O} \\
\text { / STERR |) }\end{array}$ \\
\hline EC -> EP & -0.119188 & -0.110939 & 0.031497 & 0.031497 & 3,784156 \\
EC -> OP & 0.180394 & 0.175703 & 0.048941 & 0.048941 & 3.685965 \\
EP -> OP & -0.514350 & -0.515090 & 0.042177 & 0.042177 & 12.195040 \\
ETD -> EP & 0.603603 & 0.598824 & 0.024737 & 0.024737 & 24.400823 \\
ETD -> OP & 0.025464 & 0.033265 & 0.049742 & 0.049742 & 0.511925 \\
M -> EP & 0.517345 & 0.518771 & 0.025468 & 0.025468 & 20.313527 \\
M -> OP & 0.096054 & 0.086548 & 0.043974 & 0.043974 & 2.184355 \\
WE -> EP & 0.117216 & 0.115355 & 0.018377 & 0.018377 & 6.378228 \\
WE -> OP & 0.724793 & 0.721176 & 0.024380 & 0.024380 & 29.728480 \\
\hline
\end{tabular}

Motivation (M) has a significant influence on organizational performance. Thus motivation can improve organizational performance both from external effectiveness as well as internal justice. This study support the results of research conducted by Geelmaale (2019), Mangkunegara \& Agustine (2016), and Nizam \& Shah (2015).

Employee competence (EC) has a significant influence on organizational performance. This result support Osei \& Ackah's (2015) and Hanafi \& Ibrahim's (2018) research. The work environment (WE) has a significant influence on organizational performance. It supports research by Gitonga \& Gachunga (2015) and Kegel (2017).

Employee performance (EP) has a significant influence on organizational performance. This result supports the research by Samwel (2018) and Kumar (2014). Employee Training and development has a significant influence on organizational performance, support the research by Owotunse (2018) and Younas et al. (2018).

Motivation (M) has a significant effect on employee performance. The results of this study support the results of research conducted by Olafsen et al. (2015), Mohamud et al. (2017), Kuvaas et al. (2017), Shahzadi et al. (2014), and Ali et al. (2016)

Employee competence (EC) has a significant influence on employee performance 
(EP). The results support Kurniawan et al. (2018) and Martini et al. (2018). The working environment (WE) has a significant effect on employee performance (EP). These results support the research by Putri et al. (2019) and Khoso et al. (2016).

Furthermore, to test the mediating effect on employee performance, the Sobel Ttest was conducted. The recapitulation of the mediation test is given in Table 6 .

Table 7. Recapitulation of the mediation test

\begin{tabular}{lrcr}
\hline & t-stat & p-value & Criteria \\
\hline ETD-> OP & 9,077 & 0.000 & Accepted \\
M-> OP & 0.503 & 0.615 & Rejected \\
EC-> OP & 3,612 & 0.000 & Accepted \\
WE-> OP & 18,099 & 0.000 & Accepted \\
\hline
\end{tabular}

Employee performance (EP) can mediate the effect of employee training and development (ETD) on organizational performance (OP). The results of this study reinforce and support previous empirical research, which states that employee performance mediates the relationship between training and employee development and organizational performance. (Owotunse, 2018; Younas et al., 2018; Kinisa, 2019; Samwel, 2018; Mangkunegara \& Agustine, 2016).

Employee performance (EP) is not able to mediate the influence of motivation (M) on organizational performance (OP). It happens because UPTD BPSMB employees' motivation is still low to improve individual employee performance so that ultimately it also does not affect organizational performance. It indicates that motivation in the form of internal motivation and external motivation cannot be mediated by employee performance in work quality, work quantity, attendance, and the ability to work together on organizational performance in external effectiveness and internal justice.

This result is related to the research findings stating that there is no effect of training and development on organizational performance, motivated by the mutation policy for trained staff. UPTD BPSMB is forced to return to training and development for other staff. This condition impacts the loss of employee motivation so that, in the end, it does not affect organizational performance.

These results are different from previous research that states that employee performance mediates the relationship between motivation and organizational performance. (Ali et al, 2016; Mohamud et al. 2017; Geelmaale, 2019; Mangkunegara \& Agustine, 2016; Nizam \& Shah, 2015).

Employee performance (EP) can mediate the influence of employee competence (EC) on organizational performance (OP). This result strengthens and supports previous empirical research that states that employee performance mediates the relationship between employee competence and organizational performance. (Kurniawan et al., 2018; Martini et al., 2018; Osei \& Ackah, 2015; Hanafi \& Ibrahim, 2018).

Furthermore, employee performance (EP) can mediate the influence of the work environment (WE) on organizational performance (OP). This study's results strengthen and support previous empirical research that states that employee performance mediates the relationship between work environment and organizational performance. (Putri et al., 2019; Khoso et al., 2016; Kegel, 2017; Gitonga \& Gachunga, 2015).

\section{CONCLUSION AND RECOMMENDATION}

\section{Conclusion}

Organizational performance is influenced by motivation, employee competence, work environment, and employee performance. Training and development, motivation, and work environment affect employee performance. Training and development, employee competence, work environment affect organizational performance mediated by employee performance. However, the influence of motivation on organizational 
performance cannot be mediated by employee performance.

\section{Recommendation}

Training and development programs can synchronize the needs for meeting organizational development and employee competency development to increase employees' capacity by organizational needs. Furthermore, UPTD BPSMB can become the organization that employees expect to improve competence and achievement.

Future researchers hope to discuss the training system and employee development to support the theory of organizational development and organizational competitiveness.

\section{References:}

Ali, A., Bin, L., Piang, H.J, Ali, Z. (2016). The Impact of Motivation on the Employee Performance and Job Satisfaction in IT Park (Software House) Sector of Peshawar, Pakistan. International Journal of Academic Research in Business and Social Sciences, 6(9), 297-310

Chaudry, N.I., Jariko, M.A., Mushtaque, T., Mahesar, H.A., \& Ghani, Z. (2017). Impact of Working Environment and Training \& Development on Organization Performance Through Mediating Role of Employee Engagement and Job Satisfaction. European Journal of Training and Development Studies, 4(2), 33-48

Shaikh, M.R., Tunio, R.A. \& Shah, I.A. (2017). Factors Affecting to Employee 's performance. A Study of Islamic Banks. International Journal of Academic Research in Accounting, Finance and Management Sciences, 7(1), 312-321

Ezeali \& Esiagu. (2009). Public Personnel Management: Human Capital Management strategy in 21st Century. Onitsha. Chambers Book Ltd

Geelmaale, A.M.A. (2019). Impact Of Employee Motivation On Organizational Performance. International Journal of Advance Researchs, 7(10), 166-172

Ghozali, I. (2008). Aplikasi Analisis Multivariate dengan Program SPSS. Semarang: Baand Penerbit Universitas Diponegoro

Gitonga, L. \& Gachunga, H. (2015). Influence Of Work Environment On Organizational Performance in Government Ministries in Kenya.The Strategic Journal of Business and Change Management, 2(83), 1043-1071

Hanafi, H. M., \& Ibrahim, S. B. 2018. Impact of employee skills on service performance. International Journal of Science and Research, 7(12), 587-600.

Irfan, M., Perizade, B. \& Widiyanti, M. (2019). The Effect of Leadership and Organizational Culture on Employees Performance at PT. Pertamina EP Limau Field. International Journal of Scientific \& Research Publications, 9(8), 994-1001

Kegel, P. (2017). The Impact Of The Physical Work Environment On Organizational Outcomes: A Structured Review Of The Literature. Journal of Facility Management Education and Research, 1(1), 19-29.

Khoso, A.A., Kazi, A.S., Ahmedani, M.M., Ahmed, M. \& Khoso, I.A. (2016). The impact of workplace environment that affect employee's performance in private hospitals of Hyderabad, Pakistan. International Journal of Multidisciplinary Research and Development, 3(7), 28-33

Kinisa, G.R.O. (2019). Impact of Employees' Training and Development on Organizational Performance: A Case of the National Bank of Commerce (NBC) Mwanza City. International Journal of Scientific and Research Publications, 9(8), 386-413

Kurniawan, D.A., Guswandi \& Sodikin, A. (2018). The Effect Of Competence And Motivation on Employee Performance Through Employees Capabilitieson Pt. Binasinar Amity. International Journal of Research Science \& Management, 5(5), 48-60

Kumar. R. (2014). Effect of performance appraisal on employee capability and 
organizational performance: A study of employees working in different companies in Solan district of Himachal Pradesh. Available at SSRN: https://ssrn.com/abstract=2468089.

Kuvaas, B., Buch, R. Weibel, A., Dysik, A. \& Nerstad, C.G.L (2017). Do Intrinsic and Extrinsic Motivation relate differently to Employee Outcomes? Journal of Economic Psychology, 61, 244-258. DOI: 10.1016/j.joep.2017.05.004

Mangkunegara, A.P \& Agustine, R. (2016). Effect of Training, Motivation and Work Environment on Physicians' Performance. Academic Journal of Interdisciplinary Studies, 5(1), 173-188. DOI:10.5901/ajis.2016.v5n1p173

Martini, I.A.O., Rahyudda, I.K. Sintaasih, D.K. \& Saroyeni, P. (2018). The Influence of Competency on Employee Performance through Organizational Commitment Dimension. IOSR Journal of Business and Management, 20(2), 29-37

Mohamud, S. A, Ibrahim, A. A. \& Hussein J. M. (2017). The Effect Of Motivation On Employee Performance: Case Study In Hormuud Company In Mogadishu Somalia. International Journal of Development Research, 7(11), 17001-17008.

Nizam, K. \& Shah, F.M. (2015). Impact of Employee Motivation on Organizational Performance in Oil and Gas Sector of Pakistan. IJMSR, 3(12), 7-15

Olafsen, A.H.. Halvari, H., Forest. J. \& Deci, E.L. (2015), Show them the money? The role of pay, managerial need support, and justice in a self-determination theory model of intrinsic work motivation. Scandinavian Journal of Psychology, 56(4), 447-457 DOI: 10.1111/sjop.12211

Olalere, T.O. \& Adenugba, A.A. (2013). Human Capital Development in First Bank of Nigeria PLC. Mediterranean Journal of Social Sciences, 4(2), 783-801

Osei, A.J. \& Ackah, O. (2015). Employee's Competency And Organizational Performance In The Pharmaceutical Industry, An Empirical Study Of Pharmaceutical Firms In Ghana. International Journal of Economics, Commerce and Management, 3(3), 1-9

Owotunse, E. Y. (2018). Impact of Training and Development on Employee Performance and Productivity among Members of Staff: Case Study of Kogi State Polytechnic, Ministry of Youths and Sports Kogi State, Lokoja-Nigeria, Academy Of Social Science Journal, 3(11), 1242-1248

Pasolong, H. (2019). Teori Administrasi Publik. Bandung: ALFABETA.

Putri, E.M., Maharani, V., Supriyanto, A.S. \& Mukaffi, Z. (2019). The Effect Of Work Environment On Employee Performance Through Work Discipline , International Journal of Research - GRANTHAALAYAH, 7(4), 132-140

Richard, P.J., Devinney, T.M., Yip, G.S. \& Johnson, G. (2009). Measuring Organizational Performance: Towards Methodological Best Practice. Journal of Management, 35(3), 718-804.

Samwel, J. O. (2018). Impact of Employee Training on Organizational Performance Case Study of Drilling Companies in Geita, Shinyanga and Mara Regions in Tanzania. International Journal of Human Resource Studies, 8(3), 36-41

Shahzadi, I., Javed, A. Pirzada, S.S., Nasreen, S. \& Khanam, F. (2014). Impact of Employee Motivation on Employee Performance. European Journal of Business and Management, 6(23), 159-166

Younas, W., Farooq. M., Khalil-Ur-Rehman, F. \& Zreen, A. (2018). The Impact of Training and Development on Employee Performance. IOSR-JBM, 20(7), 20-23

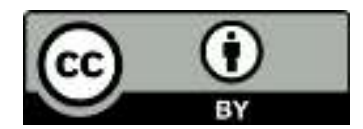

(C) 2021 by the authors. Licensee JPPD, Indonesia. This article is an open-access article distributed under the terms and conditions of the Creative Commons Attribution (CC BY) license (http://creativecommons.org/licenses/by/4.0/). 